Tropical Journal of Pharmaceutical Research February 2017; 16 (2): 343-348

ISSN: $1596-5996$ (print); 1596-9827 (electronic) (c) Pharmacotherapy Group, Faculty of Pharmacy, University of Benin, Benin City, 300001 Nigeria.

\title{
Hepatoprotective effect of Fufang-Huanglu oral liquid on $\alpha-$ naphthylisothiocyanate-induced hepatitis jaundice in mice
}

\author{
Feng Su${ }^{1}$, Zhen-zhen $\mathrm{Ma}^{2}$, Wen-jun $\mathrm{Li}^{3}$, Da-kun Zhang ${ }^{4}$, Dan-dong $\mathrm{Li}^{5}$, Zheng- \\ chen Zhang ${ }^{3}$, Fen Liu ${ }^{5}$ and Guo-qi Xie ${ }^{6 *}$ \\ ${ }^{1}$ Cardiology Department of Cardiology, ${ }^{2}$ Department of Orthopaedics \& Cardiology, ${ }^{3}$ Drug and Equipment Section, ${ }^{4}$ Department \\ of Liver Disease, ${ }^{5}$ Department of Neurosurgery, ${ }^{6}$ The 371 st Central Hospital of PLA, Xinxiang, Henan, 453000, China
}

*For correspondence: Email: xieguoqijfj@126.com, liufenpla@126.com

Received: 30 September 2016

Revised accepted: 4 January 2017

\begin{abstract}
Purpose: To investigate the effect of Fufang-Huanglu Oral Liquid (HOL) on hepatitis jaundice in mice. Methods: A total of 72 mice were divided into 6 groups $(n=12)$ : normal group, control group (model group), positive-treated group, and $3 \mathrm{HOL}$ treatment groups (7.5, 15 and $30 \mathrm{~mL} / \mathrm{kg}$ ). Mice in normal and control groups received normal saline $(20 \mathrm{~mL} / \mathrm{kg})$ orally, while positive and HOL-treated mice were orally administered Huganning tablets $(1.0 \mathrm{~g} / \mathrm{kg})$ and $\mathrm{HOL}(7.5,15$ and $30 \mathrm{~mL} / \mathrm{kg})$, respectively. After 8 days, all mice (except normal group) were orally administered a-naphthylisothiocyanate (ANIT, 100 $\mathrm{mg} / \mathrm{kg}$ ) to induce hepatitis jaundice, and sacrificed 2 days after drug administration. Serum GPT, GOT and TNF- $\alpha$, as well as liver index, MDA, SOD and lipid profiles were determined.

Results: The results showed that HOL, at all doses, significantly decreased liver index, serum GPT, serum SGOT and serum TNF- $\alpha(p<0.01)$. HOL also significantly decreased MDA, total cholesterol, TC and triglycerides, TG $(p<0.01)$, but increased liver SOD $(p<0.01)$. Histological results indicate that HOL ameliorated liver injury induced by ANIT.

Conclusion: These results showed that $H O L$ possesses significant hepatoprotective effects against liver injury.
\end{abstract}

Keywords: Fufang-Huanglu Oral Liquid, Hepatoprotective, Mice, Hepatitis, Jaundice, $\alpha$ Naphthylisothiocyanate, Liver index

Tropical Journal of Pharmaceutical Research is indexed by Science Citation Index (SciSearch), Scopus, International Pharmaceutical Abstract, Chemical Abstracts, Embase, Index Copernicus, EBSCO, African Index Medicus, JournalSeek, Journal Citation Reports/Science Edition, Directory of Open Access Journals (DOAJ), African Journal Online, Bioline International, Open-J-Gate and Pharmacy Abstracts

\section{INTRODUCTION}

It is well known that the liver is a vital intraabdominal organ which performs important biological functions such as bile secretion, synthesis of plasma proteins and lipid biosynthesis [1,2]. It is known that liver injury may arise from excessive alcohol intake, as well as exposure to various toxins and environmental pollutants. These risk factors are responsible for increasing incidence of liver injury, which may degenerate to severe liver diseases such as hepatitis, cirrhosis, and even liver cancers $[3,4]$.
Thus, it is necessary to develop more potent drugs for treatment of liver injury-related diseases.

Fufang-Huanglu Oral Liquid (HOL), a herbal prescription in traditional Chinese medicines, is clinically used for treatment of hepatitis jaundice (icteric), chronic hepatitis and hepatitis $C[5,6]$. $\mathrm{HOL}$ is composed of Cotinus coggygria, Schisandra chinensis, Sedum sarmentosum, Fructus gardenia, Fructus lycii, and Fructus jujubae [5]. Recently, HOL was developed as an effective Chinese patent medicine by the 371 
Hospital of Chinese People's Liberation Army. However, there are no animal studies so far on the health benefits of HOL. The present study was aimed at investigating the effect of $\mathrm{HOL}$ on ANIT-induced hepatitis jaundice in mice, with a view to establishing a basis for its clinical application in the treatment of liver diseases.

\section{EXPERIMENTAL}

\section{Animals}

Male specific pathogen Free (SPF) KM mice (weighing $18-21 \mathrm{~g}$ ) were purchased from the Shandong Lukang Pharmaceutical Co., Ltd (certificate no. 37009200000791) (Jinan, China). All animals were housed in a room with natural lighting at relative temperature of $20-25^{\circ} \mathrm{C}$ and humidity of $40-60 \%$. They were allowed free access to food and water. All the animal protocols used were according to the international standard protocols for the use of laboratory animals [7], and were approved by Animal Care and Use Committee of The 371 Hospital of Chinese People's Liberation Army (no. an-2015-245\#).

\section{Chemicals and reagents}

Fufang-Huanglu Oral Liquid (HOL) was obtained from the 371 Hospital of Chinese People's Liberation Army (Batch No. 20150420, Xinxiang, China); Huganning tablets were used as the positive drug and were purchased from the Guangdong Baodan Pharmaceutical Co., Ltd (Batch No. 20150701, Huizhou, China). Mouse serum glutamic-oxaloacetic transaminase (SGOT) Elisa kit (Batch No. 23037906), Mouse serum glutamate pyruvate (SGPT) Elisa kit (Batch No. 23037907), and other Elisa kits were purchased from the Beijing Dongge (DG) Boye Biotech. (Beijing, China). ANIT was product of Aladdin Chemical Reagents Co. (Shanghai, China).

\section{Animal grouping and experimental protocols}

A total of 72 mice were divided into 6 groups $(n=12)$ : normal group, control group (model group), positive treated group, and $3 \mathrm{HOL}$ treated groups $(7.5,15$ and $30 \mathrm{ml} / \mathrm{kg}$ body weight). The mice in normal and control groups were treated orally with normal saline $(20 \mathrm{ml} / \mathrm{kg}$ body weight). The commercial drug, Huganning tablets possess definite curative effect on hepatitis [8]. Mice in the positive group were treated orally with Huganning tablets (1.0 g/kg body weight). The HOL-treated mice were orally administered with $\mathrm{HOL}(7.5,15$ and $30 \mathrm{~mL} / \mathrm{kg})$. After 8 days treatment, all mice (except the normal group) were orally administered ANIT (100 mg/kg) to prepare the hepatitis jaundice mice model. Then, after 2 days of drug administration, the mice were sacrificed by decollation after collection of blood samples from the aorta abdominals under anesthesia (phentobarbital sodium, $45 \mathrm{mg} / \mathrm{kg}$ body weight through intraperitoneal injection). The blood samples were used for assay of SGPT, SGOT, and TNF- $\alpha$, while liver tissues were dissected out and used for determination of liver index, pathological changes, MDA, SOD, TC and TG.

\section{Determination of serum levels of SGPT, SGOT and TNF- $\alpha$}

Blood samples were centrifuged at $3000 \mathrm{rpm}$ for $10 \mathrm{~min}$ to obtain the serum samples, and then the serum levels of SGPT, SGOT and TNF- $\alpha$ were determined by using commercial ELISA kits according to the manufactures' instructions.

\section{Determination of MDA, SOD, TC and TG in liver tissues}

Liver tissues were homogenized and centrifuged at 3000 for $20 \mathrm{~min}$, and then commercial ELISA kits were used to determine the levels of MDA, SOD, TC and TG in the liver homogenate according to the manufactures' instructions.

\section{Histological examination of liver tissues}

Fresh liver tissue samples from each group were fixed in $10 \%$ neutral formalin and processed for light microscopy in line with standard protocols (dehydration, embedding in wax, sectioning, and staining with $\mathrm{H} \& \mathrm{E})$. The liver sections were examined in a microscope (Olympus CX22LED, Tokyo, Japan) [9].

\section{Statistical analysis}

Data are represented as mean $\pm S D(N=12)$, and statistical analysis was carried out using twotailed Student's t-test with the SPSS 17.0 (SPSS Inc., USA). $P<0.05$ was considered as significant.

\section{RESULTS}

\section{Liver index}

Results of liver index are shown in Table 1. Compared to the normal mice, the liver index values of control mice were significantly increased by treatment with ANIT $(100 \mathrm{mg} / \mathrm{kg}$ body weight; $p<0.01)$. Furthermore, the results also showed that treatment with positive drug (1 $\mathrm{g} / \mathrm{kg}$ body weight, $p<0.01)$ and $\mathrm{HOL}(30,15$ and 
$7.5 \mathrm{~mL} / \mathrm{kg}$ body weight; $p<0.01, p<0.05$ and $p$ $<0.01$, respectively) led to significant decreases in liver index when compared with the control mice.

\section{Effect of HOL on SGPT and SGOT levels}

Results of the effect of $\mathrm{HOL}$ on the serum levels of GPT and GOT are shown in Table 1. After treatment with ANIT (100 mg/kg body weight), SGPT and SGOT were significantly increased in the control mice relative to mice in the normal group ( $p<0.01$ and $p<0.01$, respectively). In addition, the results revealed that $\mathrm{HOL}$ at the doses of 30,15 and $7.5 \mathrm{ml} / \mathrm{kg}$ body weight significantly reduced both SGPT $(p<0.01)$ and SGOT $(p<0.01)$ levels.

\section{Effect of HOL on the serum level of TNF- $\alpha$}

Effects of HOL on the serum level of TNF- $\alpha$ are shown in Table 1. Serum TNF- $\alpha$ was significantly increased in control mice $(p<0.01)$, compared with the normal mice. The positive drug (Huganning tablets) at the dose of $1 \mathrm{~g} / \mathrm{kg}$ body weight significantly decreased serum level of TNF- $\alpha(p<0.01)$. Interestingly, compared to the control mice, the results indicated that serum level of TNF- $\alpha$ were significantly decreased by treatment with $\mathrm{HOL}$ at the doses of 30,15 and $7.5 \mathrm{~mL} / \mathrm{kg}(p<0.01)$.

\section{Effect of HOL on liver levels of TC and TG}

As shown in Table 1, TG and TC levels in control mice were significantly higher than that of normal mice $(p<0.01)$. The results indicated that the positive drug (1 g/kg body weight) and $\mathrm{HOL}(30$, 15 and $7.5 \mathrm{~mL} / \mathrm{kg}$ ) brought about significant decreases in the levels of TC $(p<0.01)$ and TG in liver tissues $(p<0.01)$.

\section{Effect of HOL on levels of MDA and SOD in liver tissues}

The MDA level in control mice was significantly increased $(p<0.01)$, whereas SOD level in the same group significantly decreased $(p<0.01)$ when compared to the normal mice (Table 1). Treatment with $\mathrm{HOL}$ significantly reversed this trend, by significantly reducing MDA levels while bringing about significant increases in SOD at the three doses used $(p<0.01)$.

\section{Effect of HOL on liver histology}

As shown in Figure 1, no obvious pathological changes were evident in the liver sections of normal mice. In contrast, for the control mice, the hepatic lobule boundary was unclear, and the arrangement of the hepatocytes appeared distorted. In addition, local necrosis and severe inflammatory cell infiltration were observed. Compared with the control mice, HOL treatment (30, 15 and $7.5 \mathrm{~mL} / \mathrm{kg}$ ) significantly reversed the liver injury, just like in the positive drug-treated mice. For example, a clear hepatic lobule boundary could be seen, and the local necrosis and severe inflammatory cell infiltration were obviously decreased In addition, abundant regenerated liver cells could be found in the liver tissues of HOL treated mice.

\section{DISCUSSION}

In this investigation, the effects of $\mathrm{HOL}$ on hepatitis jaundice induced by ANIT in mice were studied for the first time. Previous reports demonstrated that traditional Chinese medicines (TCM) are important resources for discovery of useful potential drugs with low side-effects, for treating various diseases. Currently, many studies have consistently demonstrated that TCMs are especially suitable agents for protection of liver function and treatment of liver diseases $[9,10]$.

The model of ANIT-induced hepatitis jaundice mice is a useful tool for investigating the hepatoprotective effects of candidate drugs $[11,12]$. The current study successfully established the model by using ANIT, and demonstrated that $\mathrm{HOL}$ could decrease liver index and degree of liver injury in the experimental model mice, indicating that $\mathrm{HOL}$ possesses potential hepatoprotective effects. Elevated SGPT and SGOT are two characteristic markers for hepatic injury $[2,13,14]$. In this study, the levels of SGPT and SGOT were sharply increased after ANIT treatment. Interestingly and importantly, HOL treatment significantly decreased the elevated SGPT and SGOT levels. TG and TC are another two biomarkers of liver function $[8,15,16]$. Similar to SGPT and SGOT, TC and TG were found to be significantly increased in the model mice, whereas the HOL treatment reversed the increases. These results indicate that $\mathrm{HOL}$ has the potential to protect the liver. TNF- $\alpha$ is a notable marker for inflammatory reactions in liver tissues [2,17]. The results of the present study revealed that $\mathrm{HOL}$ caused significant decreases in TNF- $\alpha$ levels. MDA, the major end products of lipid peroxidation, is considered a marker of oxidative stress and one of the indicators of liver injury $[9,18]$. 
Table 1: Effects of HOL on liver index and on serum levels of SGPT, SGOT, TNF- $\alpha$, TC, TG, MDA and SOD of mice with jaundice hepatitis induced by ANIT

\begin{tabular}{|c|c|c|c|c|c|c|}
\hline Group & Normal & Control & Positive & HOL-H & HOL-M & HOL-L \\
\hline $\begin{array}{l}\text { Liver index } \\
(\mathrm{mg} / \mathrm{g})\end{array}$ & $50.66 \pm 2.01^{\star \star}$ & $63.50 \pm 6.44$ & $52.02 \pm 3.15^{\star *}$ & $53.03 \pm 6.54^{\star \star}$ & $54.40 \pm 5.85^{\star}$ & $53.35 \pm 4.78^{\star *}$ \\
\hline SGPT (U/L) & $9.93 \pm 0.72^{\star *}$ & $27.35 \pm 1.58$ & $10.52 \pm 1.05^{\star *}$ & $17.26 \pm 1.81^{\star *}$ & $11.57 \pm 1.24^{\star *}$ & $10.05 \pm 0.89^{* *}$ \\
\hline $\begin{array}{l}\text { SGOT }(\mathrm{U} / \mathrm{L}) \\
\text { TNF- } \alpha(\mathrm{pg} / \mathrm{mL}) \\
\text { TC }(\mathrm{mmol} / \mathrm{L})\end{array}$ & $\begin{array}{c}6.71 \pm 1.03^{\star *} \\
983.67 \pm \\
90.83^{\star *} \\
1.53 \pm 0.24^{\star *}\end{array}$ & $\begin{array}{c}16.04 \pm 1.09 \\
1743.04 \\
\pm 118.21 \\
2.54 \pm 0.21\end{array}$ & $\begin{array}{c}6.12 \pm 0.64^{\star *} \\
985.23 \pm \\
79.68^{\star *} \\
1.59 \pm 0.25^{\star \star}\end{array}$ & $\begin{array}{c}7.01 \pm 0.56^{\star *} \\
1336.42 \pm \\
132.21^{\star *} \\
1.74 \pm 0.25^{\star *}\end{array}$ & $\begin{array}{c}5.74 \pm 0.61^{\star *} \\
1108.45 \pm \\
128.62^{\star *} \\
1.60 \pm 0.19^{\star *}\end{array}$ & $\begin{array}{c}6.93 \pm 0.89^{\star *} \\
986.34 \pm \\
89.85^{\star \star} \\
2.01 \pm 0.16^{\star *}\end{array}$ \\
\hline $\mathrm{TG}(\mathrm{mmol} / \mathrm{L})$ & $0.53 \pm 0.087^{\star *}$ & $0.89 \pm 0.071$ & $0.61 \pm 0.067^{\star *}$ & $0.67 \pm 0.065^{\star *}$ & $0.66 \pm 0.070^{\star *}$ & $0.61 \pm 0.078^{\star *}$ \\
\hline MDA (nmol/L) & $2.86 \pm 0.20^{\star \star}$ & $3.53 \pm 0.21$ & $2.88 \pm 0.17^{* \star}$ & $3.26 \pm 0.10^{\star *}$ & $3.10 \pm 0.13^{\star \star}$ & $2.89 \pm 0.10^{\star \star}$ \\
\hline $\operatorname{SOD}(\mathrm{U} / \mathrm{mL})$ & $51.00 \pm 5.25^{\star \star}$ & $25.04 \pm 2.03$ & $47.33 \pm 4.38^{\star \star}$ & $28.81 \pm 2.57^{\star *}$ & $38.03 \pm 5.52^{* *}$ & $46.77 \pm 4.72^{\star *}$ \\
\hline
\end{tabular}

HOL-H, HOL-M and HOL-L means the high, middle and low doses of HOL. Data are expressed as mean \pm SD $(n=12),{ }^{*} p<0.05,{ }^{* *} p<0.01$, compared with the control group 


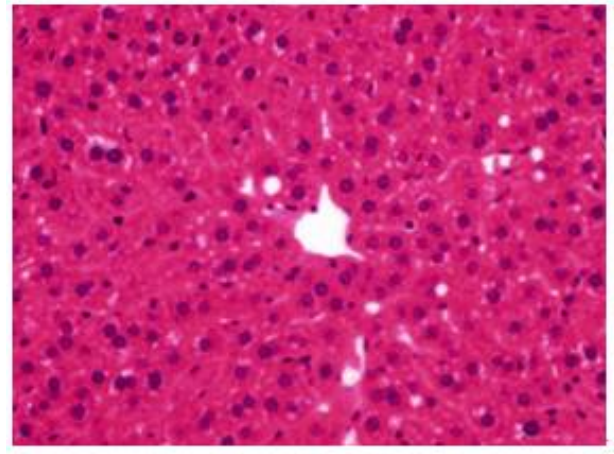

Normal $(\times 100)$

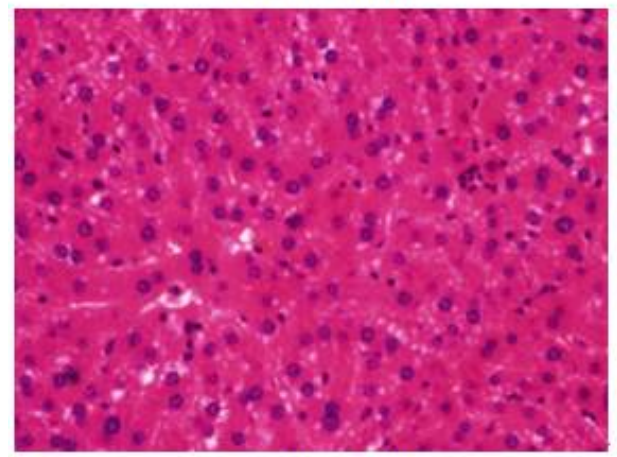

Positive $(\times 400)$

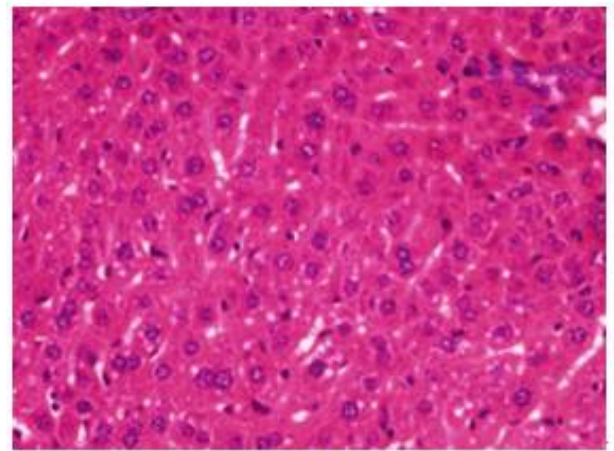

HOL-M $(\times 400)$

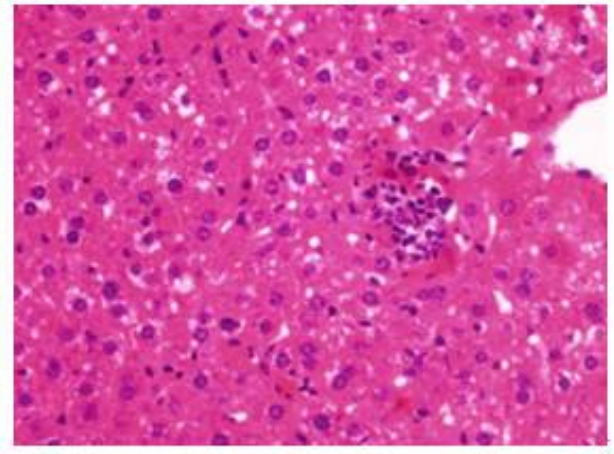

Control $(\times 400)$

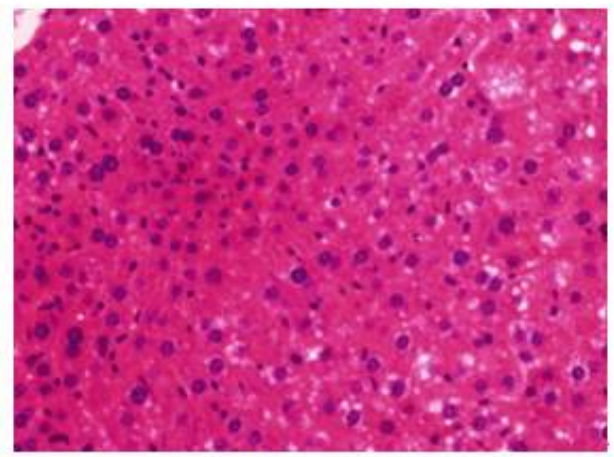

HOL-H $(\times 400)$

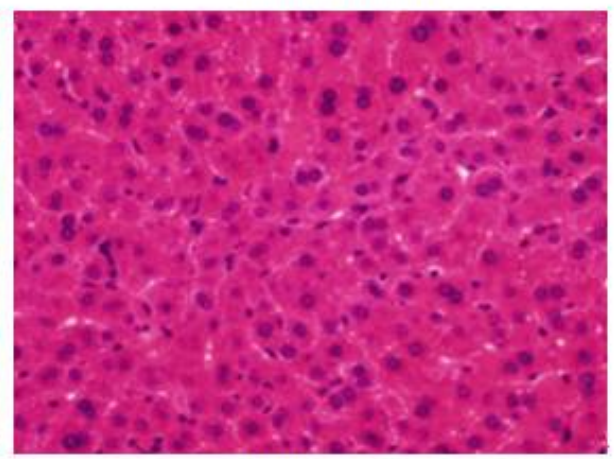

HOL-L $(\times 400)$

Figure 1: Results of the pathological examination in liver tissues

In addition, SOD is an antioxidant enzyme recognized as an inhibitor of oxidative stress $[19,20]$. HOL treatment significantly decreased MDA and concomitantly increased SOD. These results strongly suggest that $\mathrm{HOL}$ inhibited inflammatory reactions and oxidative stress in liver tissues.

\section{CONCLUSION}

The findings of this study demonstrate that $\mathrm{HOL}$ possesses good hepatoprotective effects in mice with hepatitis jaundice induced by ANIT. The potential mechanisms are closely related to decreasing SGPT and SGOT, TC, TG, TNF- $\alpha$ and MDA, as well as increasing SOD. Thus $\mathrm{HOL}$ has a potential for development as a treatment option in the management of liver injury.

\section{DECLARATIONS}

\section{Acknowledgement}

Authors are very grateful to the 371 Hospital of Chinese people's Liberation Army.

\section{Conflict of Interest}

No conflict of interest associated with this work.

\section{Contribution of Authors}

The authors declare that this work was done by the authors named in this article and all liabilities pertaining to claims relating to the content of this article will be borne by them. 


\section{Open Access}

This is an Open Access article that uses a funding model which does not charge readers or their institutions for access and distributed under the terms of the Creative Commons Attribution License (http://creativecommons.org/licenses/by 14.0) and the Budapest Open Access Initiative (http://www.budapestopenaccessinitiative.org/rea d), which permit unrestricted use, distribution, and reproduction in any medium, provided the original work is properly credited.

\section{REFERENCES}

1. Garcea G, Ong SL, Maddern GJ. Predicting liver failure following major hepatectomy. Digest Liver Dis 2009; 41: 798-806.

2. Li J, Yan HT, Che JX, Bai SR, Qiu QM, Ren L, Pan F, Sun $X Q$, Tian FZ, Li DX, Tang LJ. Effects of neurolytic celiac plexus block on liver regeneration in rats with partial hepatectomy. PLoS One 2013; 8: e73101.

3. Ghabril M, Chalasani N, Biornsson E. Drug induced liver injury: a clinical update. Curr Opin Gastroenterol 2010; 26: 222.

4. Alter MJ. Epidemiology of virtal hepatitis and HIV coinfection. J Hepatol 2006; 44:s6.

5. Shen QL, Shang DX, Ma F, Zhang ZC. Pharmacological study on anti-hepatitis effects of Cotinus coggygria Scop. Syrup Chin J Chin Mater Med 1991; 16: 746-749.

6. Su F, Shang WB, Kong $X J$, Li DD, Xie GQ, Hao SJ, Zhang ZC. Effect of compound oral liquid of Cotinus coggygria on bile flow and bile composition in rats. Acta Chin Med 2016; 31: 1128-1130.

7. National Institute of Health, USA. Public health service policy on humane care and use of laboratory animals; 2002.

8. Song JM. Evaluation on the clinical application of Huganning tablets. Evaluation Anal Drug Use Hosp Chin 2013; 13: 105-107.

9. Peng $W$, Qiu $X Q$, Shu $Z H$, Liu $Q C$, Hu MB, Han $T$, Rahman K, Qin LP, Zheng CJ. Hepatoprotective activity of total iridoid glycosides isolated from Paederia scandens (lour.) Merr. var. tomentosa. J Ethnopharmacol 2015; 174: 317-321.
10. Ali H, Kabir N, Muhammad A, Shah MR, Musharraf SG, lqabal N, Nadeem S. Hautriwai acid as one of the hepatoprotective constituent of Dodonaea viscosa. Phytomedicine 2014; 21: 131-140.

11. Wang XJ, Wang Ping, Sun H, Liu L, Wu Zm, Lv HT, Sun WJ. Protective effect and mechanism of Yin-Chen-HaoTang (YCHT) against hepatotoxicity induced by ANIT. Acta Chin Med Pharmacol 2007; 35: 17-21.

12. Prophylactic effect of four prescriptions of traditional Chinese medicine on $\alpha$-naphthylisotiocyanate and carbon tetrachloride induced toxicity in rats. Acta Pharmacol Sin 2001; 22: 1159-1167.

13. Kasdallah-Grissa A, Mornagui B, Aouani E, Hammami M, May ME, Gharbi N, Kamoun A, El-Fazza S. Resveratrol, a red wine polyphenols, attenuates ethanol-induced oxidative stress in rat liver. Life Sci 2007; 80: 10331039.

14. Omari A, Bani-Hani KE. Effect of carbon dioxide pneumoperitoneum on liver function following laparoscopic cholecystectomy. J Laparoendosc Adv Surg Tech A 2007; 17: 419-424.

15. Bychkova VI, Smirnov BM, Lesnichuk LV. Biochemical parameters of connective tissue in diagnosis of the initial stage of liver cirrhosis. Klin Lab Diagn 2003; 46:10-14

16. Habib A, Mihas AA, Abou-Assi SG, Williams LM, Gavis E, Pandak WM, Heuman DM. High-density lipoprotein cholesterol as an indicator of liver function and prognosis in non-cholestatic cirrhotics. Clin Gastroenterol Hepatol 2005; 3: 286-291.

17. Li J, Niu J, Ou S, Ye ZY, Liu DQ, Wang FC, Su YP, Wang JP. Effects of SCR-3 on the immunosuppression accompanied with the systemic inflammatory response syndrome. Mol Cell Biochem 2012; 364: 29-37.

18. Wang $Y$, Han $T$, Xue $L M$, Han $P$, Zhang $Q Y$, Huang BK, Zhang H, Ming QL, Peng W, Qin LP. Hepatotoxity of kaurene glycosides from Xanthium strumarium $L$. fruits in mice. Pharmazie 2011; 66: 445-449.

19. Dong L, He YZ, Wang YL, Dong ZY. Research progress on application of superoxide dismutase (SOD). J Agri Sci Technol 2013; 15: 53-58.

20. Gretscher RR, Streicher PE, Strauß AS, Wielsch N, Stock $M$, Wang D, Boland W1, Burse A. A common theme in extracellular fluids of beetles: extracellular superoxide dismutases crucial for balancing ROS in response to microbial challenge. Sci Rep 2016; 6: 24082. 